\title{
The effect of the ventricular system on the electric current in deep
} brain stimulation

\author{
Nada Yousif*1, Dipankar Nandi1,2, Alexander Green ${ }^{3}$, Tipu Aziz ${ }^{3}$ and \\ Xuguang Liu ${ }^{1,2}$
}

\author{
Address: ${ }^{1}$ Department of Clinical Neuroscience, Imperial College London, London, UK, ${ }^{2}$ Movement Disorders and Neurostimulation Unit, \\ Charing Cross Hospital, London, UK and ${ }^{3}$ Nuffield Department of Surgery, University of Oxford, Oxford, UK \\ Email: Nada Yousif* - n.yousif@imperial.ac.uk \\ * Corresponding author
}

from Eighteenth Annual Computational Neuroscience Meeting: CNS*2009

Berlin, Germany. 18-23 July 2009

Published: 13 July 2009

BMC Neuroscience 2009, I0(Suppl I):PI84 doi:I0.II86/I47|-2202-I0-SI-PI84

This abstract is available from: http://www.biomedcentral.com//47I-2202/I0/SI/PI84

(C) 2009 Yousif et al; licensee BioMed Central Ltd.

\section{Background}

In deep brain stimulation (DBS) for movement disorders, the electrode is implanted in the basal ganglia and thalamus, where the electrode is surrounded by gray and white matter. In contrast, when DBS is used for suppressing neuropathic pain, the electrodes are implanted in the periventricular/periaqueductal gray (PVG/PAG) region and are usually situated very close to the third ventricle and the aqueduct [1]. These structures are filled with cerebrospinal fluid (CSF), having higher conductivity and lower reactivity than that of brain tissue. We hypothesized that the proximity of these CSF volumes would have a significant effect on the current distribution and the predicted volume of tissue activated (VTA).

\section{Methods}

We constructed a finite element model of the electrode and surrounding tissue including the ventricular system, based upon a post-operative MRI of the patient [2]. This geometrical domain was used to solve the Laplace equation and to visualize the potential distribution induced by DBS [3-5]. In order to quantify the VTA, we used coupled compartmental neuronal models based on cable theory to predict the volume around the electrode in which neuronal firing could be modulated [6].

\section{Results}

Results showed that the high-conductivity CSF regions attenuated the distribution of the induced potential in the surrounding tissue, and the electric field lines were skewed towards the ventricles. This in turn affected the VTA as predicted by the compartmental axon models, such that the amplitude of the stimulus had to be doubled in the model including the ventricles in order to stimulate the same number of nearby axons. Factors such as position, size and shape of the CSF-filled space relative to the electrode position were quantified to uncover general principles of current spread in the model.

\section{Discussion}

The pain suppression effect of DBS highly depends on the location of the DBS electrode. This patient specific model indicates the influence of previously overlooked biophysical features of the surrounding brain tissues on the predictions made by FEM models of DBS. We speculate that the significant alteration of the stimulation current by the high-conductivity ventricular volumes may also have a significant impact on achieving the therapeutic outcomes.

\section{Acknowledgements}

This study was supported by a grant from the Medical Research Council of the UK, id. 78512 . 


\section{References}

I. Owen SL, Green AL, Nandi DD, Bittar RG, Wang S, Aziz TZ: Deep brain stimulation for neuropathic pain. Acta Neurochir Suppl 2007, 97: I II-I I6.

2. Green AL, Wang S, Owen SL, Xie K, Bittar RG, Stein JF, Paterson DJ, Aziz TZ: Stimulating the human midbrain to reveal the link between pain and blood pressure. Pain 2006, I 24:349-359.

3. Yousif N, Bayford R, Bain PG, Liu X: The perielectrode space is a significant element of the electrode-brain interface in deep brain stimulation: A computational study. Brain Res Bull 2007, 74:36I-368.

4. Yousif N, Bayford R, Wang S, Liu X: Quantifying the effects of the electrode-brain interface on the crossing electric currents in deep brain recording and stimulation. Neuroscience 2008, I 52:683-91.

5. Yousif $N$, Bayford $R$, Liu $X$ : The influence of reactivity of the electrode-brain interface on the crossing electric current in therapeutic deep brain stimulation. Neuroscience 2008, I 56:597-606.

6. Butson CR, Mclntyre CC: Tissue and electrode capacitance reduce neural activation volumes during deep brain stimulation. Clin Neurophysiol 2005, I I 6: I-I I.

Publish with Biomed Central and every scientist can read your work free of charge

"BioMed Central will be the most significant development for disseminating the results of biomedical research in our lifetime. "

Sir Paul Nurse, Cancer Research UK

Your research papers will be:

- available free of charge to the entire biomedical community

- peer reviewed and published immediately upon acceptance

- cited in PubMed and archived on PubMed Central

- yours - you keep the copyright 